\title{
Use of X-ray to evaluate damage caused by weevils in cowpea seeds
}

\author{
Roberto de A Melo; Victor Augusto Forti; Silvio M Cicero; Ana DLC Novembre; Paulo César T de Melo \\ USP-ESALQ, Crop Science Department, C. Postal 09, 13418-900 Piracicaba-SP; ramelo@esalq.usp.br; vaforti@esalq.usp.br; \\ smcicero@esalq.usp.br; adlcnove@esalq.usp.br; pctmelo@esalq.usp.br
}

\begin{abstract}
In Brazil, the cowpea [Vigna unguiculata (L.) Walp], is important in the Northeast Region, where it is typically grown on family farms. The importance of the damage caused to the seed quality of this species by stored pests has been described in various studies. Using X-ray, it is possible to see the internal seed structures and identify possible changes and damage. The objective of this study was to identify the damage caused by the weevil [Callosobruchus maculatus (Fabr.)] by analyzing X-ray and evaluate its relationship to the physiological quality of the cowpea seed. Three cultivars were used (IPA-206, BRS-Pajeu and BRS-Potengi) and two lines (L 281.005 and L ESP 10). The samples were exposed to X-ray and germination test to determine the cause-effect relationship between weevil damage and seed germination. X-ray images were evaluated to determine damage severity and location in the seed. Seed damage classified as severe, located in the embryonic axis or in the cotyledons, resulted in abnormal seedlings or dead seeds. The X-ray test, therefore, is efficient for evaluating weevil damage in cowpea seeds and the damage caused to be associated with any resulting adverse germination effects.
\end{abstract}

Keywords: Vigna unguiculata, Callosobruchus maculatus, image analysis, internal damage.

\section{RESUMO}

Utilização de raios $X$ na avaliação de danos causados por caruncho em sementes de feijão-caupi

No Brasil, o feijão-caupi [Vigna unguiculata (L.) Walp], tem destaque na Região Nordeste, sendo uma cultura típica da agricultura familiar. A importância dos danos causados por pragas de armazenamento em sementes da referida espécie, em relação à sua qualidade, tem sido evidenciada em vários trabalhos. Através de imagens de raios $\mathrm{X}$ é possível visualizar as estruturas internas da semente, identificando possíveis alterações e danificações. Dessa forma, esse trabalho teve o objetivo de identificar os danos causados por caruncho (Callosobruchus maculatus) e sua relação com a qualidade fisiológica das sementes de feijão-caupi, por intermédio da análise de raios X. Foram utilizadas três cultivares (IPA-206, BRS-Pajeu e BRS-Potengi) e duas linhagens (L 281.005 e L ESP 10). As amostras foram submetidas ao teste de raios $\mathrm{X}$ e ao teste de germinação, a fim de determinar a relação de causa e efeito entre os danos provocados pelo caruncho e a germinação das sementes. Nas avaliações das imagens de raios $\mathrm{X}$ foi considerada a severidade e a localização dos danos na semente. Para os danos classificados como severos, localizados no eixo embrionário e, ou nos cotilédones, as sementes originaram plântulas anormais ou as sementes estavam mortas. Portanto, o teste de raios X é eficiente para a avaliação de danos causados por caruncho em sementes de feijão-caupi, permitindo relacionar os eventuais danos com os prejuízos causados à germinação.

Palavras-chave: Vigna unguiculata, Callosobruchus maculatus, análise de imagens, danos internos. (Recebido para publicação em 18 de novembro de 2009; aceito em 15 de outubro de 2010)
(Received on November 18, 2009; accepted on October 15, 2010)

$\mathrm{T}$ he cowpea [Vigna unguiculata $(\mathrm{L}$.) Walp] is one of the most adapted, versatile and nutritious legumes among the cultivated species. It is grown on 11 million hectares in tropical and subtropical regions of Africa, Asia and the Americas (Singh et al., 2002). In Brazil, the cowpea is grown in the Northeast Region and is a typical crop of family agriculture (Freire Filho et al., 2005), being the principal subsistence crop in the semi-arid region (Silva, 2005).

The importance of the damage caused by the weevil, Callosobruchus maculatus (Fabr., 1775) (Coleoptera:
Bruchidae), to the quality of cowpea seeds has been described by various researchers (Tanzubil, 1991; Quintinela et al., 1991; Gallo et al., 2002; Silva et al., 2005; Pereira et al., 2008). This damage is a consequence of the colonization of the interior of the seeds by the larvae, and causes weight loss, commercial devaluation, a reduction in nutritive value and product hygiene by the presence of feces, eggs and insects, and also reduced seed germination (Gallo et al., 2002).

This weevil species is considered the most important pest of cowpea during storage and can cause losses of up to $60 \%$ (Tanzubil, 1991). The adult beetle is about $3 \mathrm{~mm}$ long, with brownish marks on the elytra, which form a " $\mathrm{X}$ " at rest and it survives for around 5 to 8 days. The female lays an average of 80 eggs on the seed surfaces (Quintinela et al., 1991) and emerging larvae penetrate the seeds, feeding on the internal contents. Inside the seeds, the larvae turn into pupae and, after emergence, the adults break through the tissues and start the biological cycle once more (Silva et al., 2005).

The low energy X-ray test for determining the physical quality of seeds is recommended by ISTA (1996). 
This technique was first introduced into Sweden in the 1950s, to evaluate the seed quality of forest species (Simak \& Gustafsson, 1953). According to Bino et al. (1993), when the X-ray passes through a seed, the radiation is absorbed to various degrees, depending on seed thickness, density, composition and the radiation wave length, thus creating a permanent image on radiographic film. It is a quick, non-destructive method for detecting well-formed and badly-formed seeds with mechanical damage and insect attack (ISTA, 1996) producing a permanent image on the radiographic film.

With this X-ray image, it is possible to observe the internal seed structures, identifying possible changes, especially in the embryonic axis (ISTA, 1995). According to Cicero \& Banzatto Junior (2003), the use of X-ray image analysis to evaluate seed quality is promising; it constitutes a precise method where the internal seed structures can be examined from enlarged images to show details of the damaged area, its location and extent. Since this method is non-destructive, the seed can be submitted to physiological tests and a cause and effect relationship can be established.

The technique of image analysis with X-ray has been used to evaluate the physiological potential of Cucumis melo seeds (Kamra, 1966; ObandoFlor, 2003), Pinus sylvestris L. (Simak, 1991), Solanum lycopersicum (Liu et al., 1993), Peltophorum dubium (Oliveira et al., 2003) and Cecropia pachystachya (Pupim et al., 2008). This technique also detects damage from humidity (Pinto et al., 2007) and mechanical damage to soybean seeds (Obando-Flor, 2003) and corn (Cicero et al., 1998) and also damage by stinkbugs in common bean seeds (Forti et al., 2008).

Both the physical damage caused by insects, and also other types of damage, can be quickly identified by X-ray with promising results (Simak, 1980).

The objective of this study was to identify the damage caused by weevils and its relationship with the physiological quality of cowpea seeds, by the X-ray analysis technique.

\section{MATERIAL AND METHODS}

The research was done at the Seed Analysis Laboratory of the Crop Science Department, of São Paulo University in Piracicaba, São Paulo State, on the March-June period of 2009.

The seeds from three cowpea cultivars were used (IPA-206 (IPA), BRS-Pajeu and BRS-Potengi (Embrapa)) and two lines (L ESP 10 (UFRPE/IPA) and L 281.005 (IPA)). The seeds were obtained from the institutions who owned the genotypes and they had been kept in cold and dry storage for a year.

To detect internal damage, the seeds were exposed to X-ray, using four replications of 50 randomly chosen seeds for each of the three cultivars and two lines, respectively, totaling 200 $\mathrm{X}$-rayed seeds per genotype. The seeds were placed in individual wells in a 100well acrylic plate, kept in place with a transparent adhesive tape and identified according to their position on the plate. The X-ray was obtained by placing the acrylic plate with the seeds directly on an X-ray film (Kodak MIN-R EV 2000), measuring $18 \times 24 \mathrm{~cm}$, at a distance of $57 \mathrm{~cm}$ from the X-ray emission source (FAXITRON X-Ray, model MX-20), using an intensity of $25 \mathrm{kV}$ and a 40 second exposure.

The films were developed in a processor (Hope X-Ray, model 319 Micromax) and then the X-ray images were scanned (Umax, model Power Look 1100) and transferred to a computer. Image analyses permitted the enlargement and evaluation of each X-rayed seed.

The germination test was done after the X-ray procedure, according to the Rules for Seed Analysis (RSA) (Brasil, 2009). For the germination test, the seeds (in groups of 10) were distributed equidistantly on the upper third of the substrate over a paper towel "Germitest". The paper sheets were moistened with a quantity of water equivalent to 2.5 times their weight. The paper rolls were then placed in a germinator and kept at $25^{\circ} \mathrm{C}$. Five days after starting the test, the seedlings (normal and abnormal) and the dead seeds were photographed with a digital camera (Nikon, model D1) attached to a computer. Later, the images of the obtained seedlings (normal and abnormal) and dead seeds were compared, side-by-side, with the $\mathrm{X}$-ray images so that any weevil damage could be associated with any changes in seed germination.

Damage was classified according to criteria described by Cicero et al., (1998) with some modifications. Each seed was given two rankings, the first referring to damage to the embryonic axis and the second, to any cotyledon damage. When there was no damage to the embryonic axis or to the cotyledons, that is, no damage was observed, a ranking of 1.1 was given to the X-ray image of the seed. Light damage is that observed in both the embryonic axis and the cotyledons, but which does not affect normal seedling formation; thus, a 2.2 was given to cases where the damage was classified as not being severe, either for the embryonic axis or for the cotyledons. On the other hand, damage was classified as severe when it was greater on the embryonic axis or cotyledons and interfered with seed germination, stopping normal seedling formation; damage to the cotyledons, next to the embryonic axis region, was also generally considered as severe, since it affects nutrient translocation to the embryonic axis during germination. Therefore, this last situation was given a ranking of 3.3, signifying severe damage to the embryonic axis and cotyledons.

The experimental design was completely random, with 5 treatments (three cultivars and two lines) and 4 replications of 50 seeds each. Analysis of variance was done using the $\mathrm{F}$ test and the Tukey test to compare means at a $5 \%$ probability level.

\section{RESULTS AND DISCUSSION}

The simultaneous examination of the internal seed images (X-ray), seedlings and dead seeds after the germination test permitted a diagnosis for each case, resulting in the establishment of a cause and an effect, as was done in common beans by Mondo et al. (2009).

Table 1 shows mean values in percentages for damage intensity detected by X-ray, caused by weevils to the embryonic axis region and, or the cotyledons, in the three cultivars and two lines analyzed. 
Table 1. Mean values (\%) for seeds with different damage rankings given for weevil damage to the embryonic axis and cotyledons in the 5 lots evaluated by X-ray (valores médios (\%) de sementes com diferentes notas atribuídas aos danos causados pelo caruncho. no eixo embrionário e nos cotilédones. nos cinco lotes avaliados por meio de raios X). Piracicaba, USP/ESALQ, 2009.

\begin{tabular}{|c|c|c|c|c|}
\hline \multirow{2}{*}{ Damage site } & \multirow{2}{*}{ Genotypes } & \multicolumn{3}{|c|}{ Damage ranking ${ }^{1}$} \\
\hline & & 1 & 2 & 3 \\
\hline \multirow{5}{*}{ Embryonic axis } & L ESP 10 & $100.0 \mathrm{a}^{2}$ & $0.0 \mathrm{~b}$ & $0.0 \mathrm{~b}$ \\
\hline & IPA-206 & $63.5 \mathrm{~b}$ & $10.5 \mathrm{a}$ & $26.0 \mathrm{a}$ \\
\hline & L 281.005 & $95.0 \mathrm{a}$ & $0.5 \mathrm{~b}$ & $4.5 \mathrm{~b}$ \\
\hline & BRS-Pajeu & $98.5 \mathrm{a}$ & $0.0 \mathrm{~b}$ & $1.5 \mathrm{~b}$ \\
\hline & BRS-Potengi & $94.5 \mathrm{a}$ & $1.0 \mathrm{~b}$ & $4.5 \mathrm{~b}$ \\
\hline CV $(\%)$ & & 4.82 & 39.81 & 40.48 \\
\hline \multirow{5}{*}{ Cotyledons } & L ESP 10 & $100.0 \mathrm{a}$ & $0.0 \mathrm{c}$ & $0.0 \mathrm{c}$ \\
\hline & IPA-206 & $21.5 \mathrm{~d}$ & $29.5 \mathrm{a}$ & $49.0 \mathrm{a}$ \\
\hline & L 281.005 & $84.0 \mathrm{c}$ & $9.5 \mathrm{~b}$ & $6.5 \mathrm{~b}$ \\
\hline & BRS-Pajeu & $95.5 \mathrm{~b}$ & $3.0 \mathrm{bc}$ & $1.5 \mathrm{c}$ \\
\hline & BRS-Potengi & $88.8 \mathrm{bc}$ & $4.5 \mathrm{bc}$ & $7.0 \mathrm{~b}$ \\
\hline $\mathrm{CV}(\%)$ & & 5.71 & 46.20 & 13.38 \\
\hline
\end{tabular}

${ }^{1}$ Damage rankings $1=$ Undamaged; $2=$ Light damage; $3=$ Severe damage; ${ }^{2}$ In the column, for each site of damage, means followed by the same letter do not differ among themselves based on the Tukey test, at the $5 \%$ probability level (valores de dano $1=$ não observado; $2=$ dano não severo; $3=$ dano severo; ${ }^{2} \mathrm{Na}$ coluna, para cada valor de dano, médias seguidas da mesma letra não diferem entre si pelo teste de Tukey, a 5\% de probabilidade).

Table 2. Values (\%) for normal seedlings (NS), abnormal seedlings (AS) and dead seeds (DS), obtained in the germination test and respective rankings given to X-ray images for weevil damage (valores (\%) de plântulas normais (NS), de plântulas anormais (AS) e de sementes mortas (DS) obtidos no teste de germinação e respectivas notas atribuídas às imagens de raios X, para danos por caruncho). Piracicaba, USP/ESALQ, 2009.

\begin{tabular}{lcccccccccc}
\hline \multirow{2}{*}{ Genotypes } & & \multicolumn{10}{c}{ Damage ranking* } \\
\cline { 3 - 11 } L ESP 10 & NS & 95.5 & 0 & 0 & 0 & 0 & 0 & 0 & 0 & 0 \\
& AS & 4.5 & 0 & 0 & 0 & 0 & 0 & 0 & 0 & 0 \\
& DS & 0 & 0 & 0 & 0 & 0 & 0 & 0 & 0 & 0 \\
\hline \multirow{3}{*}{ IPA-206 } & NS & 8.0 & 12.0 & 5.5 & 0.5 & 1.5 & 2.0 & 0.5 & 0 & 0.5 \\
& AS & 11.5 & 10.5 & 12.5 & 0 & 2.5 & 4.0 & 0 & 2.5 & 18.5 \\
& DS & 1.0 & 0.5 & 2.0 & 0 & 0 & 0 & 0 & 0 & 4.0 \\
\hline \multirow{4}{*}{ L 281.005 } & NS & 71.5 & 8.5 & 1.5 & 0 & 0.5 & 0 & 0 & 0 & 2.0 \\
& AS & 11.5 & 0 & 0.5 & 0 & 0 & 0 & 0 & 0 & 2.0 \\
& DS & 1.0 & 0.5 & 0 & 0 & 0 & 0 & 0 & 0 & 0.5 \\
\hline \multirow{3}{*}{ BRS-Pajeunyyyyyyyyyyyy} & NS & 94.0 & 3.0 & 0 & 0 & 0 & 0 & 0 & 0 & 0.5 \\
& AS & 1.5 & 0 & 0 & 0 & 0 & 0 & 0 & 0 & 0.5 \\
& DS & 0 & 0 & 0 & 0 & 0 & 0 & 0 & 0 & 0.5 \\
\hline \multirow{3}{*}{ BRS-Potengi } & NS & 8.0 & 1.0 & 0 & 0 & 0 & 0.5 & 0 & 0 & 1.5 \\
& DS & 2.5 & 0 & 0 & 0 & 0 & 0 & 0 & 0 & 0.5 \\
\hline
\end{tabular}

$* 1=$ undamaged, $2=$ light damage, $3=$ severe damage. The first algarism of the ranking refers to the embryonic axis and the second algarism to the cotyledons $(1=$ danos não observados, $2=$ danos não severos, $3=$ danos severos. $O$ primeiro algarismo da nota refere-se ao eixo embrionário e o segundo aos cotilédones).
Seeds of cultivar IPA-206 showed more damage to the embryonic axis and cotyledons, which was ranked as severe (3.3), compared to the other genotypes. However, the occurrence of light damage was less for the BRSPajeu and BRS-Potengi cultivars and the L ESP 10 and L 281.005 lines, with these four genotypes showing higher mean number of seeds with no damage either to the embryonic axis or to the cotyledons.

The percentages of normal and abnormal seedlings and dead seeds observed in the germination test, for seeds which have weevil damage and were evaluated by X-ray, are shown in Table 2. The results demonstrate that those seeds which suffered no damage to the embryonic axis or cotyledons (Figure 1A) mostly produced normal seedlings (Figure 1B) after the evaluation of germination on the day stipulated by the RSA for the first count. This can be seen for the cultivars BRSPajeu and BRS-Potengi and the lines L ESP 10 and L 281.005 (Table 2). However, some seeds where no damage was observed (ranking 1.1) produced abnormal seedlings; according to Burg et al. (1994), this type of problem may be due to infection by microorganisms, physiological deterioration and, or tissue death.

For damage ranked as severe, both to the cotyledons and embryonic axis, for seeds from the five genotypes, there was a direct relationship between damage and the number of abnormal seedlings and dead seeds, considering the first count of the germination test. The number of dead seeds in the five genotypes was low, with the highest percentage (7.5\%) for IPA-206.

Seeds with weevil damage are shown in Figures 1C, 2A, 2C and 2E. Figure $1 \mathrm{C}$, shows a seed with severe damage only to the cotyledons (ranking 1.3), resulting in an abnormal seedling (Figure 1D). According to Cicero et al. (1998), damages to cotyledons, which restrict nutrient translocation to the embryonic axis, or which directly affect the embryonic axis, adversely affect seed germination.

Figure 2A shows a seed with light damage to the embryonic axis and 


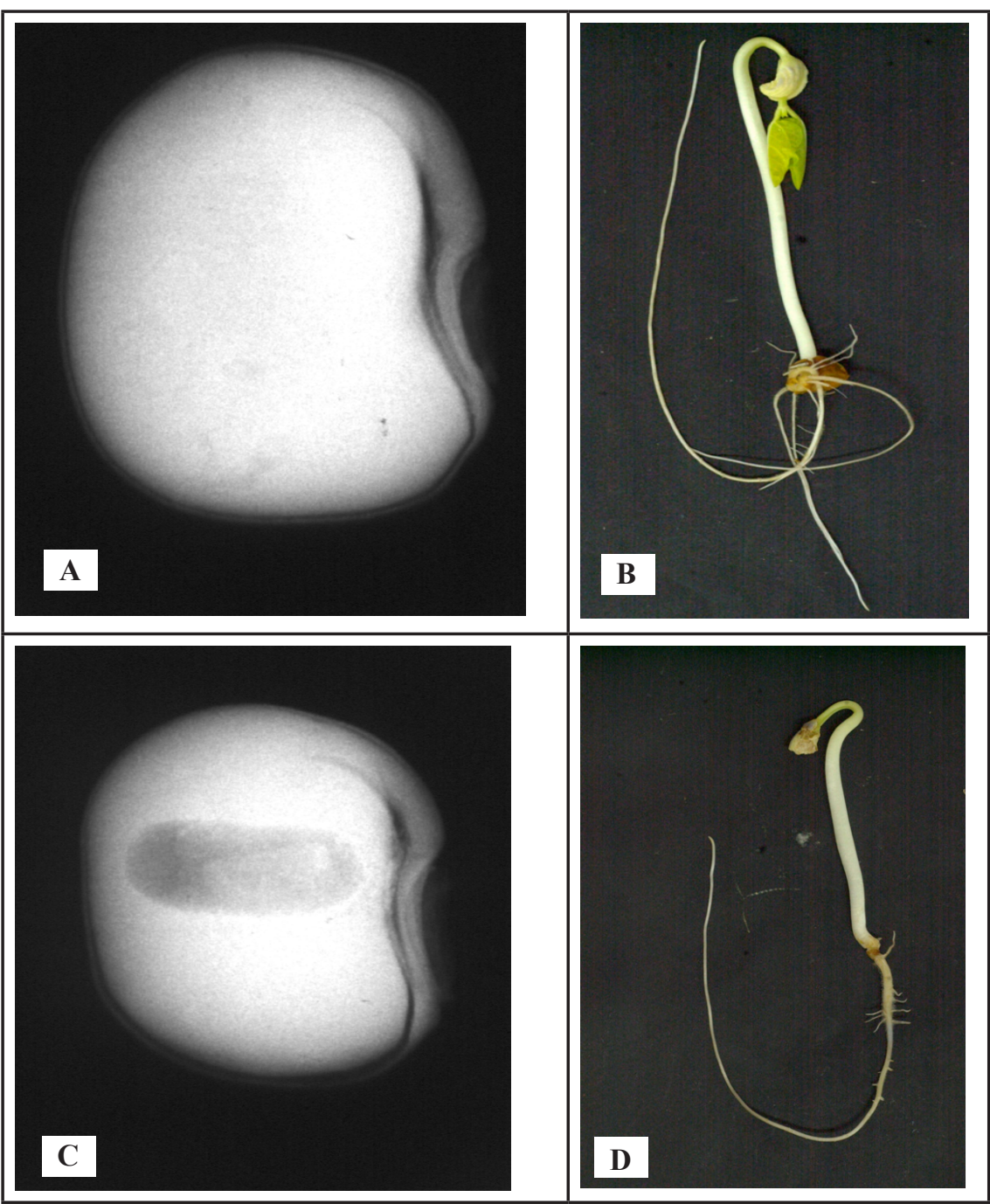

Figure 1. Image of a seed of the L ESP 10 line obtained from X-ray, undamaged by weevils (A), ranking 1.1, resulting in a normal seedling (B). Image of the seed of cultivar IPA-206 obtained from X-ray, with weevil damage $(\mathrm{C})$, with ranking 1.3, resulting in an abnormal seedling (D) (imagem de semente da linhagem L ESP 10 obtida por meio do teste de raios $\mathrm{X}$, sem dano por caruncho (A), nota 1.1, originando uma plântula normal (B). Imagem de semente da cultivar IPA-206 obtida por meio do teste de raios X, com dano por caruncho (C), nota 1.3, originando uma plântula anormal (D)). Piracicaba, USP/ESALQ, 2009.

severe damage to the cotyledonal region, ranked as 2.3 and gave rise to an abnormal seedling (Figure 2B).

Figure $2 \mathrm{C}$ shows a seed classified as 3.2, which has severe damage on the embryonic region and light damage on the cotyledonal region, resulting in an abnormal seedling (Figure 2D).

Figure 2E presents a seed with severe damage to the cotyledons and the embryonic axis, classified as 3.3, which produced a dead seed on the germination test (Figure 2F). Based on an analysis of the seeds of the three cultivars and two lines, it was seen that severe damage to the embryonic axis and cotyledons resulted in dead seeds or abnormal
Science of USP/ESALQ, where the research project was done; The institutions which supported this research project: CAPES, CNPq, UFRPE, IPA, Embrapa and Hortivale Ltda.

\section{REFERENCES}

BINO RJ; AARTSE JW; BURG WJ. 1993. Nondestructive X-ray of Arabidopsis embryo mutants. Seed Science Research 3: 167-170.

BRASIL. Ministério da Agricultura, Pecuária e Abastecimento. Regras para análise de sementes. Secretaria de Defesa AgropecuáriaBrasília: MAPA/ACS, 2009. 395p.

BURG WJ; AARTESE JW; ZWOL RA; JALINK H; BINO RJ. 1994. Predicting tomato seedling morphology by X-ray analysis of seeds. Journal of American Society for Horticultural Science 119: 258-263.

CICERO SM; HEIJDEN GWAM; BURG WJ; BINO RJ. 1998. Evaluation of mechanical damage in seeds of maize (Zea mays L.) by $\mathrm{X}$-ray and digital imaging. Seed Science and Technology 26: 603-612.

CICERO SM; BANZATTO JUNIOR HL. 2003. Avaliação do relacionamento entre danos mecânicos e vigor, em sementes de milho, por meio da análise de imagens. Revista Brasileira de Sementes 25: 29-36.

FORTI VA; CICERO SM; PINTO TLF. 2008. Análise de imagens na avaliação de danos mecânicos e causados por percevejo em sementes de feijão. Revista Brasileira de Sementes 30: 121-130.

FREIRE FILHO FR; RIBEIRO VQ; BARRETO PD; SANTOS AA. 2005. Melhoramento genético. In: FREIRE FILHO FR; LIMA JAA; RIBEIRO VQ (eds). Feijão-caupi: avanços tecnológicos. Brasília: Embrapa Informação Tecnológica. p. 29-75.

GALLO D; NAKANO O; SILVEIRA NETO S; CARVALHO RPL; BATISTA GC; BERTI FILHO E; PARRA JRP; ZUCCHI RA; ALVES SB; VENDRAMIM JD; MARCHINI LC; LOPES JRS; OMOTO C. 2002. Entomologia agrícola. Piracicaba: FEALQ. 920p.

ISTA. Internacional Seed Testing Association. International rules for testing seed. 1995. Seed Science and Technology 13: 300-520.

ISTA. International Rules for Seed Testing. 1996. Seed Science and Technology 24: 336p.

KAMRASK. 1966. Determination of germinability of melon with X-ray contrast method. Proceedings of the International Seed Testing Association 31: 719-729.

LIU Y; BURG WJ; AARTSE JW; ZWOL RA; JALINK H; BINO RJ. 1993. X-ray studies on changes in embryo and endosperm morphology during priming and inhibition of tomato seeds. Seed Science Research 3: 171-178.

MONDO VHV; GOMES JUNIOR FG; PUPIM TL; CICERO SM. 2009. Avaliação de danos mecânicos em sementes de feijão por meio da análise de imagens. Revista Brasileira de Sementes 31: 27-35.

OBANDO-FLOR EP. 2003. Avaliação de danos mecânicos em sementes de soja por meio da 


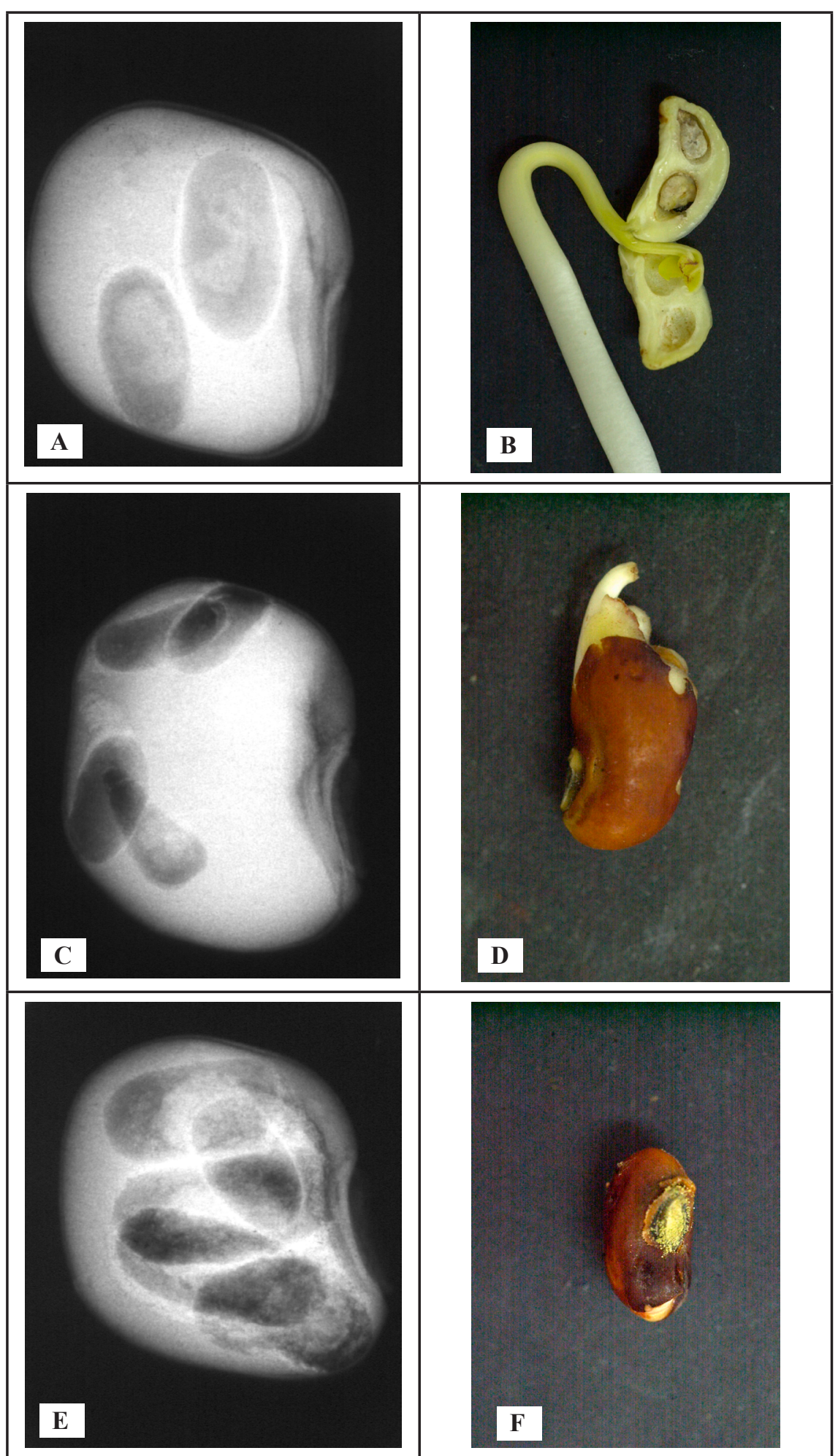

Figure 2. Image of a seed of cultivar IPA-206 obtained from X-ray, with weevil damage (A), with ranking 2.3, resulting in an abnormal seedling (B). Image of a seed of cultivar BRS-Pajeu obtained from X-ray, with weevil damage (C), with ranking 3.2, resulting in an abnormal seedling (D). Image of the seed of cultivar IPA-206 obtained from X-ray, with severe weevil damage (E), with ranking 3.3, resulting in a dead seed (F) (imagem de semente da cultivar IPA-206 obtida por meio do teste de raios X, com dano por caruncho (A), nota 2.3, originando uma plântula anormal (B). Imagem de semente da cultivar BRS-Pajeu obtida por meio do teste de raios X, com dano por caruncho (C), nota 3.2, originando uma plântula anormal (D). Imagem de semente da cultivar IPA-206 obtida por meio do teste de raios X, com dano severo por caruncho (E), nota 3.3, originando semente morta (F)). Piracicaba, USP/ESALQ, 2009. análise de imagens. Piracicaba: USP-ESALQ. 72p (Tese doutorado).

OLIVEIRA LM; CARVALHO MLM; DAVIDE AC. 2003. Utilização do teste de raios $\mathrm{X}$ na avaliação da qualidade de sementes de canafístula (Peltophorum dubium (Spengel) Taubert. Revista Brasileira de Sementes 25: 116-120.

PEREIRA ACRL; OLIVEIRA JV; GONDIM JUNIOR MGC; CÂMARA CAG. 2008. Atividade inseticida de óleos essenciais e fixos sobre Callosobruchus maculatus (FABR., 1775) (Coleoptera: Bruchidae) em grãos de caupi [Vigna unguiculata (L.) Walp.]. Ciência e Agrotecnologia 32: 717-724.

PINTO TLF; CICERO SM; FORTI VA. 2007. Avaliação de danos por umidade, em semente de soja, utilizando a técnica da análise de imagens. Revista Brasileira de Sementes 29: 31-38.

PINTO TLF; CICERO SMC; FRANÇA NETO JB; FORTI VA. 2009. An assessment of mechanical and stink bugs damage in soybean seed using X-ray analysis test. Seed Science and Technology 37: 110-120.

PUPIM TL; NOVEMBRE ADLC; CARVALHO MLM; CICERO SM. 2008. Adequação do teste de raios $\mathrm{X}$ para avaliação da qualidade de sementes de embaúba (Cecropia pachystachya Trec.). Revista Brasileira de Sementes 30: 28-32.

QUINTINELA ED; NEVES BP; QUINDERÉ MAW; ROBERTS DW. 1991. Principales plagas del caupi em el Brasil. Goiânia: Embrapa-CNPAF, $37 \mathrm{p}$.

SILVA GS. 2005. Nematóides. In: FREIRE FILHO FR; LIMA JAA; RIBEIRO VQ (eds). Feijão-caupi: avanços tecnológicos. Brasília: Embrapa Informação Tecnológica, p. 487-497.

SILVA PHS; CARNEIRO JS; QUINDERÉ MAW. 2005. Pragas. In: FREIRE FILHO FR; LIMA JAA; RIBEIRO VQ (eds). Feijão-caupi: avanços tecnológicos. Brasília: Embrapa Informação Tecnológica. p. 367-402.

SIMAK M. 1980. X-Radiography in research and testing of forest tree seeds. Report SUASDepartment of Silviculture, Umea-Sweden, n. 3, p. 1-34.

SIMAK M. 1991. Testing of forest tree and shrub seeds by X-radiography. In: GORDON AG; GOSLING P; WANG BSP (eds). Tree and shrub seed handbook Zurich: ISTA. p.1-28.

SIMAK M; GUSTAFSSON A. 1953. X-ray photography and sensitivity in forest tree species. Hereditas 39: 458-468.

SINGH BB; EHLERS JD; SHARMA B; FREIRE FILHO FR. 2002. Recent progress in cowpea breeding. In: FATOKUN CA; TARAWALI AS; SINGH BB; KORMAWA PM; TAWO M. (eds). Challenges and opportunities for enhancing sustainable cowpea production. Ibadan: IITA. p. 22-40.

TANZUBIL PB. 1991. Control of some insect pests of cowpea (Vigna unguiculata) with neem (Azadirachta indica) in Northern Ghana. Tropical Pest Management 37: 216-217. 